\title{
The Pattern of Community Service on Faculty of Tarbiyah and Teacher Training Lectures
}

\author{
Muhammad Munadi \\ Institut Agama Islam Negeri (IAIN) Surakarta, Indonesia \\ munadimahdiputra@gmail.com \\ Subar Junanto \\ Institut Agama Islam Negeri (IAIN) Surakarta, Indonesia \\ subarjunanto82@gmail.com \\ Retno Wahyuningsih \\ Institut Agama Islam Negeri (IAIN) Surakarta, Indonesia \\ retnowahyuningsih2008@gmail.com
}

\begin{abstract}
The objectives of this research are to see the pattern of Faculty of Tarbiyab and Teacher Training lecturers in doing community service, the urgency of the lecturers to choose the pattern of community service as done so far, and the obstacle of community service. This research employed qualitative field method. The subjects of this research were the lecturers of Faculty of Tarbiyah and Teacher Training of LAIN Surakarta. Meanwhile, the research informants were the officials in Faculty of Tarbiyah and Teacher Training environment whose leading sector was community services and the community around the lecturers who did community services. Research data was gathered through interview methods, observation and documentation. Data triangulation was done to validate the data. Data obtained from these methods were analyzed interactively. Patterns that can be used in doing community service in Faculty of Tarbiyah and Teacher Training and IAIN
\end{abstract}


Surakarta is the pattern of Cquba, which is divided into 5 areas of community services. They are: engage contacts with individuals, groups and organizations thus can benefit the expertise of the university, contribute to the spiritual growth of the society, offering teaching services and research services, expertise exchange, providing access to facilities and / or programs, as well as special services related to the charter, vision, mission, goals and objectives of the university.

Keywords: Community service; Academically Based Community Services (ABCS) pattern; non Academically Based Community Services (non $A B C S$ )

\begin{abstract}
Abstrak
Penelitian ini bertujuan mengetahui gambaran pola pengabdian para dosen FITK di lingkungan masyarakatnya, urgensipara dosen memilih pola pengabdian seperti yang dilakukan selama ini, dan kendala pengabdian pada masyarakat. Metode penelitian ini menggunakan metode kualititatif lapangan. Subjek penelitian ini adalah dosen Fakultas Ilmu Tarbiyah dan Keguruan I AIN Surakarta. Sedangkan informan penelitian adalah pejabat di lingkungan FITK yang leading sectornya adalab pengabdian masyarakat dan warga masyarakat sekitar dosen tersebut melakukan pengabdian. Data penelitian akan dikumpulkan melalui metode wawancara, observasi dan dokumentasi. Teknik pemeriksaan keabsahan data menggunakan triangulasi. Data yang diperoleh dari beberapa metode tersebut akan dianalisis secara interaktif. Hasil penelitian ini menunjuk.kan bahwa Pola yang dipakai dalam pengabdian masyarakat di FITK dan IAIN Surakarta dengan pola Czuba, yang membagi menjadi 5 bidang pengabdian masyarakat yaitu: Terlibat kontak dengan individu, kelompok dan organisasi sehingga bisa berbagi manfaat dan dan keablian yang dimiliki universitas, berkontribusi terhadap pertumbuban rohani masyarakat, penawaran layanan fungsi pengajaran, dan penelitian, pertukaran keablian, penyediaan akses ke fasilitas dan/atau program, serta layanan khusus yang berkaitan dengan piagam, visi, misi, tujuan dan sasaran universitas.
\end{abstract}

Kata Kunci: Pengabdian kepada masyarakat; pengabdian masyarakat berbasis akademik; pengabdian masyarakat berbasis non akademik. 


\section{A. Introduction}

The duty of lecturers is set in the Tri Dharma of the University which includes; education \& teaching, research, and service. Education and teaching are actualized by teaching activities conducted routinely every semester. Especially in the Faculty of Tarbiyah and Teacher Training (Fakultas Ilmu Tarbiyah dan KeguruanFITK) of IAIN Surakarta, the lecturers are not confused to be able to fulfill the minimum education and teaching obligation due to the large number of classes and students in FITK.

Research activities are also an obligation that should not be abandoned by a lecturer. In a year, a lecturer at least has to do a research. The lecturers always try to fulfill the obligation to do research by participating in research activities held by the Ministry of Religious Affairs or elsewhere. As in 2013, the Ministry of Religious Affairs (Kementerian Agama-Kemenag) Directorate of Islamic Higher Education (Diktis) provided competitive research opportunities for lecturers within the Ministry of Religious Affairs. Specifically from FITK lecturers, there were about 10 groups or about 25 people participating in the activity (documentation from the Ministry of Religious Affairs Directorate of Diktis, 2013). The two activities were education / teaching and research which are mandatory activities that must be reported by a lecturer. Therefore, in the process, the lecturer will work hard so that the two activities can be fulfilled.

In contrast to service, even though equally as a duty but in its reporting, service may be replaced by other supporting components. Thus, there were many lecturers who paid less attention to the form of service in society. On the other hand, being a lecturer is considered as a respectable profession, a smart person, and caring for the community. They are required to be able to help the community, involving themselves in all community activities. Especially as the lecturers of PTAIN, IAIN lecturers are heavily involved in religious 
activities in the community. As stated by Rahardjo ${ }^{1}$ that universities are not a historical ivory tower, but is a container that becomes the meeting place of applicable ideas for community empowerment. In this case, what is expected from the higher education world is the emergence of innovative ideas for the development. In addition, the Give-Get Model for University-School Partnerships model, rural and urban schools benefit from college-based partnerships and cooperation programs ${ }^{2}$. The benefits include the development of teachers' capacity in schools, and the provision of variety of learning resources for each student.

However, from the service done by the lecturers of IAIN Surakarta, especially FITK lecturers, the pattern of service done by them has not been found yet. Therefore, this research is considered important to be followed up in order to find the service pattern of FITK IAIN Surakarta lecturers. This research aims to find the FITK lecturers' service pattern in the community, the reason the lecturers choose the pattern of service as done so far, and the obstacle in doing community service.

This research employed qualitative field method aimed to understand the phenomena from participants' point of view, social and institutional context at FITK IAIN Surakarta. The research design is clearly described and appropriate for the purpose of the study. The research design is clearly described and appropriate for the purpose of the study. The subjects of this research were lecturers of Faculty of Tarbiyah Science and Teacher Training of IAIN Surakarta. Meanwhile, the research informants were the officials in FITK environment whose leading sector was community services and the community around the lecturers who did community services. The research data were gathered through interview, observation and documentation method. Data triangulation was

1 Rahardjo, M. (2010). Sejarah Sosial Pengabdian kepada Masyarakat. Retrieved June 14, 2016, from https://www.uin-malang.ac.id/r/100501/sejarah-sosial-pengabdiankepada-masyarakat.html

2 Smith, A. (2009). Perceptions of a university-school collaborative partnership. The University of Alabama. 
done to validate the data. The data obtained from these methods were analyzed interactively.

\section{B. Discussion}

\section{Service Patterns Used By FITK Lecturer So Far}

Community services performed by lecturers at FITK are very diverse viewed from the background of the department or the previous lecturers' study program and educational background as well as the religious background of the lecturer and their residence. Those different backgrounds make different actualization of community service too. They are based on educational background, workplace background, or working background at Islamic University. FITK lecturers are more dominant conducting community service activities in the religious sector. It can be seen in the table below:

Table 3. Community Services in Religious Activities

\begin{tabular}{|c|c|c|c|}
\hline No & Activities & $\begin{array}{l}\text { Academically } \\
\text { Based } \\
\text { Community } \\
\text { Services } \\
\text { (ABCS) }\end{array}$ & $\begin{array}{l}\text { non } \\
\text { Academically } \\
\text { Based } \\
\text { Community } \\
\text { Services (non } \\
\text { ABCS) }\end{array}$ \\
\hline 1. & $\begin{array}{ll}\text { Village } & \text { Development } \\
\text { Mentoring } & \end{array}$ & & $V$ \\
\hline 2 & $\begin{array}{l}\text { Teaching Al-Quran Reading } \\
(T P A)\end{array}$ & & V \\
\hline 3 & $\begin{array}{l}\text { Friday Sermon (Khutbah), } \\
\text { Islamic Routine Sermon, } \\
\text { and Ramadhan Sermon }\end{array}$ & & V \\
\hline 4 & $\begin{array}{l}\text { Active in Islamic Study } \\
\text { Organization }\end{array}$ & & V \\
\hline 5. & $\begin{array}{l}\text { Islamic study group } \\
\text { (pengajian) mentoring }\end{array}$ & $\nabla$ & \\
\hline 6 & $\begin{array}{l}\text { Khotib of Eid al-Fitr and } \\
\text { Eid al-Adha }\end{array}$ & & V \\
\hline 7 & The committee of Qurban & & V \\
\hline 8. & Holly Qur'an Study & & V \\
\hline 9 & $\begin{array}{l}\text { Forming Qur'an reading } \\
\text { groups }\end{array}$ & & $\mathrm{V}$ \\
\hline 10 & The Mosque Organizer & & $\mathrm{V}$ \\
\hline
\end{tabular}


The table above shows that religious activities conducted within the framework of community service was not based on the lecturers' academic background. However, apparently the activities were based on habitual, not because of community service on the basis of academics. It was stated by one of the respondents:

I do community service because since my childhood, I was educated in a strong religious environment so it is just like back to basic. No more ${ }^{3}$.

The statement indicates that community service on the FITK lecturers is based on the initial environment where they grew since they were small, that was in religious field. This phenomenon indicates that the attachment of this religious field is reasonable. Other respondents somewhat has different statement:

Not all the things in life must be related to the educational background but because I work at PTAIN then the community demands that I bave to take part in the religious field. There is a bidden demand that whatever your initial education was, when you have entered the work at PTAIN then just like an automatism you are required to work, with people in the religion field. ${ }^{4}$

Besides the habitual development in the religious field due to the factors of childhood experience, there is also because of the community demands to take part in the religious field since the workplace is under the Ministry of Religious Affairs. Lecturers as part of the community are also involved in community service in the field of society in general.

Table 4. Community Service In Social Activities

\begin{tabular}{|c|c|c|c|}
\hline No & Activities & $\begin{array}{l}\text { Academically } \\
\text { Based } \\
\text { Community } \\
\text { Services } \\
\text { (ABCS) }\end{array}$ & $\begin{array}{l}\text { non } \\
\text { Academically } \\
\text { Based } \\
\text { Community } \\
\text { Services (non } \\
\text { ABCS) }\end{array}$ \\
\hline 1. & Competition Jury & & 8 \\
\hline
\end{tabular}

3 Interview with respondent A

4 Interview with respondent $\mathrm{B}$ 


\begin{tabular}{lll}
\hline 2 & $\begin{array}{l}\text { Social role based on the husband's } \\
\text { employment }\end{array}$ & $\mathrm{V}$ \\
\hline 3 & $\begin{array}{l}\text { The member of Al-Qur'an Reading } \\
(T P A / T Q A) \text { Coordination Board } \\
\text { in district level }\end{array}$ & \\
\hline 4 & $\begin{array}{l}\text { Organizer of PKK (Development } \\
\text { of Family Welfare) }\end{array}$ & \\
\hline 5. & $\begin{array}{l}\text { Organizer of Dasa Wisma } \\
\text { (Neighborhood mothers social } \\
\text { group for the development of } \\
\text { family welfare) }\end{array}$ \\
\hline 6 & Mosque Organizer & \\
\hline
\end{tabular}

The table above shows that in the field of society, lecturers performed community services as a board of social organizations - dasa wisma, PKK organizer, mosque organizer, and Al-Qur'an Reading (TPA/TQA) Coordination Board. The involvement of the lectures in social organizations was from the lowest level like dasa wisma to district level. This phenomena is not related to the profession of lecturers yet, lecturers should also work in the field of professional societies in addition to social duties in general.

The data of community service conducted by the lecturers related to the profession of the lecturers in the field of education is presented as follows:

Table 5. Community Service in Educational Activities

\begin{tabular}{llll}
\hline No & \multicolumn{1}{c}{ Activities } & $\begin{array}{c}\text { Academically } \\
\text { Based } \\
\text { Community } \\
\text { Services (ABCS) }\end{array}$ & $\begin{array}{c}\text { non } \\
\text { Academically } \\
\text { Based } \\
\text { Community } \\
\text { Services (non } \\
\text { ABCS) }\end{array}$ \\
\hline 1. & $\begin{array}{l}\text { The speaker of PKK based on } \\
\text { educational background }\end{array}$ & V & \\
\hline 2 & $\begin{array}{l}\text { TPA (Al-Qur'an Reading) } \\
\text { Teaching }\end{array}$ & V & \\
\hline 3 & Teacher mentoring & & \\
\hline 4 & $\begin{array}{l}\text { 'Child Development' Consultant } \\
\text { On TKIT Al Fath, Pucangan, }\end{array}$ & \\
Kartasura. & &
\end{tabular}




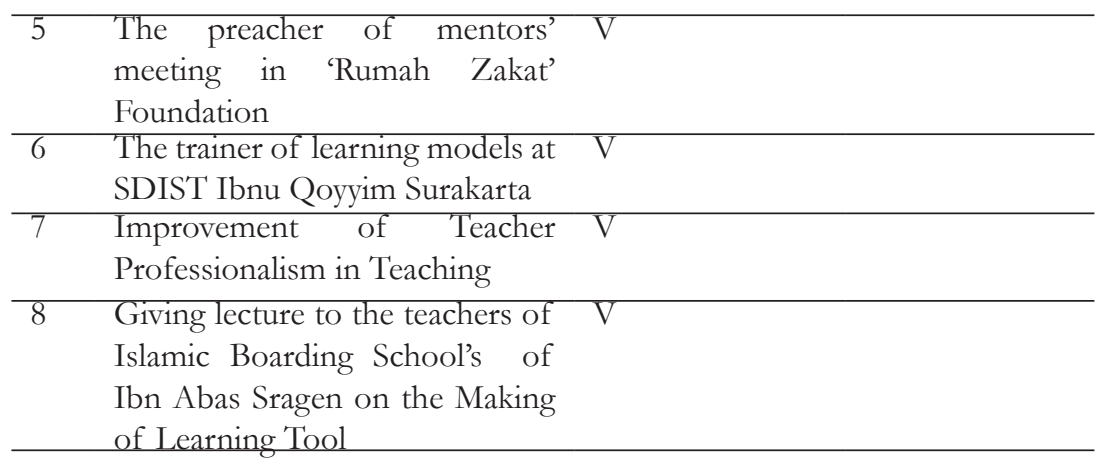

Community service in the field of education was performed by academic-based lecturers. However, its implementation was not much based on the results of the research. The service is integrated with the research. This kind of community service implementation was on teaching mentoring points. Such kind of implementation was performed by the School Laboratory and the Center for Policy Education Studies (Pusat Studi Kebijakan Pendidikan-PSKP). DIPA FITK has funded The School Laboratory to conduct this activity since 2012. It is presented in the following table:

Table 6. Types of Community Service

\begin{tabular}{|c|c|}
\hline Year & In accordance with FITK \\
\hline 2010 & 0 \\
\hline 2011 & 0 \\
\hline 2012 & The Development, Training, Mentoring of Madrasah/School \\
\hline \multirow[t]{4}{*}{2013} & $\begin{array}{l}\text { 1. Workshop on Preparation of Teaching Materials in Madrasah } \\
\text { / School }\end{array}$ \\
\hline & 2. Training on the Implementation and Development of Active \\
\hline & Learning Model for Madrasah Teachers \\
\hline & 3. Mentoring lessons for MI Teachers \\
\hline \multirow[t]{3}{*}{2014} & $\begin{array}{l}\text { 1. Community Service in the form of Madrasah / School } \\
\text { Mentoring }\end{array}$ \\
\hline & $\begin{array}{l}\text { 2. Workshop on the Preparation of Teaching Materials in } \\
\text { Madrasah / School }\end{array}$ \\
\hline & $\begin{array}{l}\text { 3. Training on the Implementation and Development of Active } \\
\text { Learning Model for Madrasah Teachers }\end{array}$ \\
\hline Total & \\
\hline
\end{tabular}

Table 4 shows that there were community services in the pure framework of community service by mentoring madrasab teachers around IAIN Surakarta. The Madrasah includes MI Darussalam I, 
MI Al Islam Kartasura, MI Darussalam II, MIM Pucangan, and MTsN Filial Kartasura. Only MTsN Filial Kartasura had specific mentoring. The mentoring attached to the research was conducted by the Center for Policy Education Studies.

The amount of community services from year to year there is increasing. Here's the table:

Table 7. The Amount of Community Services

\begin{tabular}{cc}
\hline Year & Funded by FITK \\
\hline 2010 & 0 \\
\hline 2011 & 0 \\
\hline 2012 & 1 activity \\
\hline 2013 & 2 activities dan 1 activity \\
\hline 2014 & 7 activities \\
\hline Total & 11 Activities \\
\hline
\end{tabular}

This number indicates that there is concern from FITK in the development of community service activities. Starting from 1 activity developed into 3 in 2013 and turned into 7 activities in 2014. The funding source came from FITK and also from one of the NGOs in Jakarta named TIFA. Here is the table:

Table 6. Community Service Total Funding

\begin{tabular}{cccc}
\hline Year & $\begin{array}{c}\text { Funded by } \\
\text { FITK }\end{array}$ & $\begin{array}{c}\text { Funded by External } \\
\text { Organization }\end{array}$ & Total \\
\hline & 0 & 0 & 0 \\
\hline 2011 & 0 & 0 & 0 \\
\hline 2012 & 30.080 .000 (DIPA FITK) & 0 & 30.080 .000 \\
\hline 2013 & 74.000 .000 (DIPA FITK) & $270.000 .000($ TIFA) & 344.000 .000 \\
\hline 2014 & 112.560 .000 (DIPA FITK) & Not yet identified & 112.560 .000 \\
\hline Total & $\mathbf{2 1 6 . 6 4 0 . 0 0 0}$ & $\mathbf{2 7 0 . 0 0 0 . 0 0 0}$ & $\mathbf{4 8 6 . 6 4 0 . 0 0 0}$ \\
\hline
\end{tabular}

In 2010 till 2011 had not identified because in those two years the status of the institution was still STAIN, so there was no separate funding for community service activities. Community service in 2013 had increased sharply because of the funds from the State University Operational Aid Fund (Bantuan Operasional Perguruan Tinggi Negeri-BOPTN). The funds were more intended to increase the quality of the university which based on majors or study programs.

The funds from TIFA were obtained through a proposal 
by PSKP in the year prior to the change of STAIN Surakarta to IAIN. This PSKP is unique in doing community service because it is research-based and attached to the research. PSKP manager states:

The model of community-based service research and attached to the research is taken because of funding demands, therefore it must be so. It means that at the beginning the research activities conducted on a small group of MI in Kartasura District. After that, it is applied to a large group (MI teachers in Kartasura District, Baki District, and Gatak District) with mentoring process. The mentoring process lasts for one year.

The explanation shows that community services performed by FITK lecturers were very varied but still patterned on two trends, Academically Based Community Services (ABCS) pattern and non Academically Based Community Services (non ABCS) pattern. However, the most visible trend was non-Academically Based Community Services (non ABCS), so it is less supportive to the development of study areas and study program. Besides, community services tended to be done by giving lectures and not based on research results. Community services were still individual and not based on cooperation agreement. However, a breakthrough done by PSKP in cooperation with TIFA Foundation undertook a very long service for one year by mentoring teachers starting from the need of training assessment (NTA) to the implementation in their madrasah by observing outputs and outcomes. The outcomes were in the form of: active learning, Lesson Plan documents, and module documents. Besides, during the mentoring, the teachers got learning intake through newsletters published by PSKP in cooperation with PSKP. This last activity has a strong Academically Based Community Services (ABCS). ABCS can make science in college can grow and can be grounded with the reality in the community.

The target of community service is uniform, that is in educational institutions, in this case is the education personnel. It is because the study in FITK is in the field of education and teaching, thus it is reasonable if the services of the lecturers are in the field of

5 Interview with PSKP Program Manager 
education and teaching. Their service was still limited to teaching, not yet spread to the development of educational institution capacity which includes not only teacher education and management staff but also non-teaching staff, such as librarians, labors, media experts, curriculum developers and counselors. If the target is expanded, it can make the madrasab grow together with the university. Furthermore, community service can be a free institutional promotion tool. This limited target of service is illustrated in the following table:

Table 9. Community Service Target

\begin{tabular}{|c|c|c|c|}
\hline Year & $\begin{array}{c}\text { In accordance with } \\
\text { FITK }\end{array}$ & Target & Executor \\
\hline 2010 & 0 & 0 & 0 \\
\hline 2011 & 0 & 0 & 0 \\
\hline 2012 & $\begin{array}{l}\text { The Development, Training, } \\
\text { Mentoring of Madrasah/School }\end{array}$ & $\begin{array}{l}\text { Madrasah } \\
\text { Teachers (MI } \\
\text { Darussalam I-II, } \\
\text { MIM Pucangan, } \\
\text { dan MTsN Filial) }\end{array}$ & School Lab \\
\hline \multirow[t]{3}{*}{2013} & $\begin{array}{l}\text { 1. Workshop on Preparation } \\
\text { of Teaching Materials in } \\
\text { Madrasah / School }\end{array}$ & $\begin{array}{l}\text { MTsN Filial } \\
\text { Teachers }\end{array}$ & School Lab \\
\hline & $\begin{array}{l}\text { 2. Training on the } \\
\text { Implementation and } \\
\text { Development of Active } \\
\text { Learning Model for Madrasah } \\
\text { Teachers }\end{array}$ & & \\
\hline & $\begin{array}{l}\text { 3. Mentoring lessons for MI } \\
\text { Teachers }\end{array}$ & $\begin{array}{l}\text { MI Teachers } \\
\text { in Gatak, Baki } \\
\text { and Kartasura } \\
\text { District. }\end{array}$ & PSKP \\
\hline 2014 & $\begin{array}{l}\text { 1. Community Service in the } \\
\text { form of Madrasah / School } \\
\text { Mentoring } \\
\text { 2. Workshop on the Preparation } \\
\text { of Teaching Materials in } \\
\text { Madrasah / School } \\
\text { 3. Training on the } \\
\text { Implementation and } \\
\text { Development of Active } \\
\text { Learning Model for Madrasab } \\
\text { Teachers }\end{array}$ & & $\begin{array}{l}\text { School Lab } \\
\text { Program }\end{array}$ \\
\hline
\end{tabular}


The table shows that the community services performed by the School Laboratory were still limited in Kartasura District area and were still limited in the field of learning and management of Madrasah. They are in contrast to those undertaken by PSKP which provided mentoring to strengthen the capacity of Madrasah teachers in the field of learning around Kartasura, Baki, and Gatak. PSKP funds were not from DIPA FITK but from the TIFA Foundation. The community service executors were more dominantly implemented by the School Lab and still depended on DIPA FITK funds. Faculty of Tarbiyah and Language has several mentoring madrasah / schools such as:
a. MI Darussalam 1 Kartasura
b. MI Darussalam 2 Kartasura
c. MI Al-Islam Kartasura
d. MI Muhammadiyah Gonilan Kartasura
e. MI Guppi Gatak
f. MTs Al-Islam Polokarto Sukoharjo

The activities that have been conducted on the mentoring madrasah are:

a. Workshop of PAIKEM (Active, Innovative, Creative, Effective, and Fun Learning)

b. Teaching Material Workshop

c. Deepening mathematical material (by facilitating the present of exemplary teachers)

d. Training on the formulation of the institution's Vision and Mission based on SWOT Analysis

e. Training on the accreditation preparation by inviting speakers from school which accredited A, namely Jama'atul Ikhwan. (Interview with the Head of the School Laboratory and the school laboratory report document). 
The school expects the continuous cooperation / facilitation, especially by facilitating seminars and training related to the deepening of the material.

\section{The Reason of Used Patterns in Community Service}

Lecturers argue that community service is more based on personal appointment and not coordinated by academic field, either through Faculty or IAIN Surakarta because it is simpler. Here's the opinion:

"I conduct community service in the form of direct appointment from one of the educational institutions that asked me for a lecture about learning. Thus, it was just a personal introduction with the institution, so that I do not have to do research first. Besides that, the official letter from the educational institution addressed personally to me".

The similar statement was also given by other respondents

It is true that I was asked by one of the educational institutions because there is an alumnus who works there delivering materials related to early childhood education. But I still ask the agency to write letter to LP2M in order to appoint me to be the speaker?

Those two statements indicate that the community service conducted by the lecturers was more likely to use lecturing in which the appointment was not based on institution. It happened because of the lack of silaturabmi (get-together/relationship) of Faculty and IAIN Surakarta institutions with institutions around Surakarta. Here is the statement of one of the lecturers:

Our weakness as an institution is weak on inter-institutional relationship. What happens is the strong relationship between the lecturers and the existing institutions. The university should think back to its role in society. Especially cooperation within the framework of growing together ${ }^{8}$

The opinion is recognized by bureaucratic stakeholders, the statement as followed:

\footnotetext{
6 Interview with respondent $C$

7 Interview with respondent D

8 Interview with respondent $\mathrm{E}$
} 
It is acknowledged that we as an institution still rarely invite or visit institutions around LAIN so that the activities in those institutions do not involve us as an institution. There is a wisdom on the organization and working procedure changes where the vice rector and vice dean of the field three take care the problem of cooperation. Preliminary links can be started by field three, it will be followed up by field one and supported by field two?

The statement above indicates that there is a need of synergy in all fields of faculties and institutions at IAIN Surakarta so that it can boost accreditation and become a promotional tool for all stakeholders.

\section{Obstacle Experienced By The Lecturer When Conducting Community Service}

The university has tri dharma, namely: teaching, research and community service. During this time, dharma that is often abandoned and less structured with the research and teaching is community service. Nevertheless, the implementation of community service is not as easy as its coordination with teaching / learning and research activities. It is because it has not been structured with teaching and research activities. Supposedly the three activities in the tri dharma of the university must be in line so that the contribution of those three in society is seen.

Besides that, the research activities should be followed up with community service activities with the support of large funds. Thus the research activities are not just a collection of less meaningful results for the development of science and society who have financed it. This was conveyed by the following respondents:

Research should not only be stacked on library shelves and community service units. If the condition is still like this thus the results of the research are less meaningful for the development of higher education. Therefore, it is necessary to account the results of research to the community through community service activities $^{10}$.

9 Interview with respondent $\mathrm{F}$

10 Interview with respondent $G$ 
This opinion indicates that during this time, research reports are still only stacked on the shelves of the book hence it is less meaningful for the development of science in the university. Problem solving is needed in this case. Other respondents expressed their opinions on the integration of research and community service:

The obligation to implement the results of the research to the community through community service needs a large amount of funding. However, funding alone is not sufficient thus reorientation of the research that leads to community service is needed. There should be a research road map that integrates with community service ${ }^{11}$.

So far, there is no roadmap to unify the tri dharma of the university yet, whereas this road map is needed to unite the three worlds that initially had the same goal of developing knowledge. During this time, they are walking alone so that teaching has not nuanced research and service has not nuanced research. Hence, there is an up-dating of knowledge in university. Automatically, if it goes then the knowledge that students get is a new science and tested in the community.

The linkage between research and teaching is community service. Therefore the community service must be based on teaching and also research. The picture is as follows:

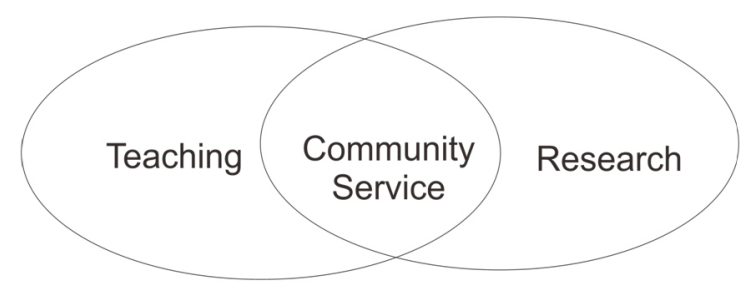

Figure 2. The Linkage between Tri Dharma of the University

Community service is one form of tri dharma of the university. The other dharma are teaching and research. Dharma of service is also a part of the accreditation assessment in Standard

11 Interview with respondent $\mathrm{H}$ 
7. This standard establishes the quality of the research, service to the community, and cooperation in every institution either on the level of study program / department, faculty or university. Those standards are a benchmark of research quality, community service, and cooperation that is held related to the development of the undergraduate study program's quality. Service to the community is conducted as a manifestation of the expertise's contribution, the utilization of educational outcomes, and / or research in the field of science, technology and / or art, in order to fulfill the demand and / or initiate the improvement of the nation's quality of life.

A good undergraduate study program has a management system in collaboration with external stakeholders to organize and improve the quality of academic programs continuously. The results of the collaboration are well-managed for academicinterest and as the embodiment of the undergraduate study program's accountability as nonprofit institutions. A good undergraduate study program is able to design and utilize collaborative programs involving active participation of the undergraduate study program also utilize and improve the expertise and quality of the undergraduate study program resources. The most noticeable use of expertise is through community service.

In this research, it is found that so far the pattern of community service done by lecturers is still patterned on non Academically Based Community Service ( $\mathrm{n}-\mathrm{ABCS}$ ), it should be Academically Based Community Service (ABCS). Community service is patterned on non-Academic Based Community Service (n-ABCS) because it is simpler viewed from the personal side without much attention to the scientific process and bureaucracy procedures. Besides, this pattern is not necessarily be funded by the institution. This is different from the community service patterned Academically Based Community Service (ABCS) which requires a scientific method with a deductive or inductive way of thinking so that the level of the 
lecturers' expertise can be seen. In addition, it requires bureaucratic procedures. This is in the following framework of opinion:

There are two ways in which Higher Education disseminates higher knowledge: by teaching and by community service. Teaching is primary. Indeed, teaching bigher knowledge can be seen as encapsulating a form of community service, especially if one takes seriously the view that higher knowledge is a public $\operatorname{good}^{\prime 2}$ (Morrow, 2009).

There are two ways in which universities are disseminating higher knowledge: by teaching and doing community service. Teaching is the primary. Indeed, teaching higher knowledge can be seen as encapsulating the form of community service, especially if one takes seriously the view that higher knowledge is a public good. Bureaucratic procedures are used because the external agencies cannot directly point out who can assist community service activities. It is because the external agencies might not select based on the expertise of the appointed person. To minimize this situation, socialization and publication of lecturers' expertise map in universities that can be accessed through the college website is needed. Therefore, the external institution will still write institutional letter to the rector or dean to appoint the lecturers they want. This conditions make the university is able to have a control of designated person's concentration and can be a tool for determining cost drivers in budgeting. Such an oriented budget facilitates the measurement of lecturers' performance.

The following third way can be used as a reference: Thirdly, HEIs can contribute to local communities, culture and environment. Involvement with the local social and natural environment can take several forms ranging from community service activities to local case studies and pilot projects (e.g. energy efficiency programs, coastal zone management, etc. $)^{13}$.

12 Morrow, W. (2009). Bounds of Democracy Epistemological Access in Higher Education. South Africa: HSRC Press.

13 Brunner, J. J., \& Gacel-avilà, J. (2012). Higher Education in Regional and City Development. Colombia: OECD. 
Third, universities can contribute to local communities, cultures and the environment. The involvement with the local social and natural environment can take several forms ranging from community service activities to local case studies and pilot projects (for example the energy efficiency programs, coastal area management, etc.). This opinion indicates that community service can empower local potential to develop. In addition, it can empower remote and underdeveloped area to be a developed area socially and economically. Locality can be a reference for universities to develop science based on local wisdom. Such phenomena can make universities become not ivory tower. According to Wendler ${ }^{14}$, the concept of "the Ivory Tower" is used in a negative sense when referring to universities to indicate a separation from reality and the practical concerns of the world. The university is called the ivory tower when there is separation between the reality of society with the ideal study of the university. This is where community service is necessary to connect the reality and idealism, so that the science studied in university can be meaningful for the community development.

The third way of community service is in accordance with the one stated in the Mission and functions of the University on the World Declaration On Higher Education For The Twenty-First Century Award: Vision And Action ${ }^{15}$ which states:

advance, create and disseminate knowledge through research and provide, as part of its service to the community, relevant expertise to assist societies in cultural, social and economic development, promoting and developing scientific and technological research as well as research in the social sciences, the bumanities and the creative arts

University needs to develop, create and disseminate knowledge through research and provide, as part of its service to the community, relevant expertise to assist society in cultural, social and

14 Wendler, W. V. (2010). Higher Education Policy Commentary. Illinois: Southern Illinois University Carbondale.

15 UNESCO. (1998). World Declaration On Higher Education For The Twenty-First Century: Vision And Action. Paris. Retrieved from http://www.unesco.org/education/ educprog/wche/declaration_eng.htm 
economic development, promoting and developing scientific and technological research as well as research in the social sciences, the Humanities and the creative arts. The document becomes guidance for universities in which the results of the research should be able to solve the problems of the community, at least the community where the university is located, so that the field of culture, social and economic can be developed.

In order to avoid ivory tower, it can be through the concept model of $\mathrm{Czuba}^{16}$ on community service at IAIN Surakarta in general and FITK in particular, as follows:

Table 10. Alternative Models of Community Service at FITK and IAIN

\begin{tabular}{|c|c|c|c|}
\hline Field & & Service at IAIN level & Service at FITK level \\
\hline $\begin{array}{l}\text { Engage contact with } \\
\text { individuals, groups } \\
\text { and organizations } \\
\text { to share the benefits } \\
\text { and expertise of the } \\
\text { university. }\end{array}$ & & $\begin{array}{l}\text { Mentoring of public } \\
\text { Islamic study group } \\
\text { (pengajian) or profession } \\
\text { according to the study } \\
\text { program } \\
\text { Utilization of } \\
\text { laboratory and library } \\
\text { owned by the Faculty } \\
\text { and IAIN } \\
\text { Utilization of lecturers' } \\
\text { expertise and other } \\
\text { functional skills }\end{array}$ & $\begin{array}{l}\text { 1. Mentoring of } \\
\text { formal and } \\
\text { nonformal } \\
\text { madrasah and } \\
\text { pesantren (Islamic } \\
\text { boarding school) } \\
\text { 2. Islamic spiritual } \\
\text { mentoring and } \\
\text { missionary } \\
\text { institution of } \\
\text { the university } \\
\text { in schools / } \\
\text { universities } \\
\text { Utilization } \\
\text { of lecturers' } \\
\text { expertise based } \\
\text { on the general } \\
\text { education } \\
\text { and religious } \\
\text { education }\end{array}$ \\
\hline
\end{tabular}

16 Czuba, J. (2005). Relationship between university functions and community service at Divine Word University, 2(May), 57-67. 


\begin{tabular}{|c|c|c|}
\hline $\begin{array}{l}\text { Contribute to the } \\
\text { spiritual growth of the } \\
\text { society }\end{array}$ & $\begin{array}{l}\text { 1. Distribution of khotib } \\
\text { (jum'at, Eid Al-Fitrand } \\
\text { Eid al-Adha), preacher } \\
\text { of PHBI and preacher } \\
\text { of Ramadhan. } \\
\text { 2. Mentoring of routine } \\
\text { Islamic study groups } \\
\text { (pengajian) } \\
\text { 3. Moslem youth } \\
\text { mentoring }\end{array}$ & $\begin{array}{l}\text { 1. Mentoring of } \\
\text { madrasah teachers } \\
\text { / teachers of } \\
\text { formal, non- } \\
\text { formal religious } \\
\text { education and } \\
\text { PAI (Islamic } \\
\text { Education) in } \\
\text { public schools } \\
\text { Expert counselor } \\
\text { on the spiritual } \\
\text { section of Islam } \\
\text { and LDK. } \\
\text { Education } \\
\text { section } \\
\text { mentoring on the } \\
\text { youth moslem in } \\
\text { the mosque }\end{array}$ \\
\hline $\begin{array}{l}\text { Offering teaching and } \\
\text { learning as well as } \\
\text { research services }\end{array}$ & $\begin{array}{l}\text { 1. Collaboration for } \\
\text { developing mosque data } \\
\text { base and Islamic study } \\
\text { group (pengajian) } \\
\text { 2. Research cooperation } \\
\text { in the development of } \\
\text { jama'ah satisfaction }\end{array}$ & $\begin{array}{l}\text { 1. Mentoring of } \\
\text { scientific works } \\
\text { to madrasah } \\
\text { teachers / } \\
\text { teachers of } \\
\text { formal, non- } \\
\text { formal religious } \\
\text { education and } \\
\text { PAI in public } \\
\text { schools } \\
\text { 2. Research } \\
\text { collaboration for } \\
\text { the development } \\
\text { of madrasah data } \\
\text { base and its } \\
\text { resources }\end{array}$ \\
\hline Exchange of expertise & 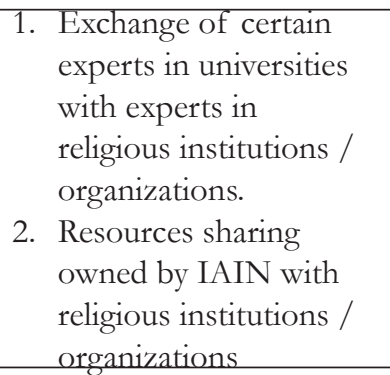 & $\begin{array}{l}\text { 1. Professor goes } \\
\text { to school and } \\
\text { madrasah } \\
\text { 2. Exchange of } \\
\text { lecturers / other } \\
\text { functional to } \\
\text { madrasah or vice } \\
\text { versa }\end{array}$ \\
\hline
\end{tabular}




\begin{tabular}{|c|c|c|}
\hline $\begin{array}{l}\text { Provision of access } \\
\text { to facility and / or } \\
\text { program }\end{array}$ & $\begin{array}{l}\text { 1. Providing the use of } \\
\text { IAIN laboratory and } \\
\text { library } \\
\text { 2. Provide opportunity to } \\
\text { participate in science } \\
\text { programs owned by } \\
\text { IAIN }\end{array}$ & $\begin{array}{l}\text { 1. Giving } \\
\text { opportunity } \\
\text { for sharing use } \\
\text { of facilities } \\
\text { owned by each } \\
\text { institution } \\
\text { 2. Opening new } \\
\text { programs } \\
\text { required by } \\
\text { formal, non- } \\
\text { formal and } \\
\text { pesantren }\end{array}$ \\
\hline $\begin{array}{l}\text { Specialized services at } \\
\text { universities relating to } \\
\text { the university's charter, } \\
\text { vision, mission, goals } \\
\text { and objectives. }\end{array}$ & $\begin{array}{l}\text { Providing special } \\
\text { services related to the } \\
\text { majors in IAIN Surakarta. }\end{array}$ & $\begin{array}{lr} & \text { Providing } \\
\text { special } & \text { services } \\
\text { in } & \text { developing } \\
\text { other institutions' } \\
\text { capability according } \\
\text { to the majors own by } \\
\text { FITK. }\end{array}$ \\
\hline
\end{tabular}

The roadmap can be used as a model for FITK and IAIN Surakarta to be the initial reference for the improvement of community service of the lecturers.

\section{Conclusion}

Community service performed by FITK lecturers was very varied but still patterned on two trends, Academically Based Community Services (ABCS) pattern and non Academically Based Community Services (non ABCS) pattern. However, nonAcademically Based Community Services (n-ABCS) was more dominant, so it was less supportive to the development of study areas and study programs. The community services were more likely by giving lectures rather than based on the results of research because the researches were still limited as the one that pile up on the shelves of the institutions and researchers. Community service was still individual and not based on cooperation agreement. There is a need to be encouraged from the institution so that service is based on the results of the research. It means there is a link between 
research and teaching with community service. Thus, the research can be grounded in the community because it is used in the real world in society.

The reason why the non-Academically Based Community Services (n-ABCS) pattern was more dominant used by the lecturer because it was simpler without having to base on the research. Furthermore, the difficult bureaucratic system made the lecturers did services as a personal relationship with the place of the community service. Academic-based research should be encouraged by the ease of bureaucracy and FITK must have each lecturer's expertise database published through the faculty sub-domain, making it easier for the community when it comes to utilizing the expertise of lecturers. Encouragement from the institution is needed so that the service is based on the results of the research. It means that there is a link between research and teaching with community service. Thus research can be grounded in the community because it is used in the real world of society.

The obstacles of community service on lecturers when it must be conducted with the pattern of Academically Based Community Services (ABCS) was there was no roadmap linkage between tri dharma of the university and no policy that regulated the obligations in which the researchers had to apply the results in the form of community service. The road map of the relationship between research and teaching with community service must be initiated by faculty so that it can boost the achievement of accreditation.

Alternative patterns that can be used in community service at FITK and IAIN Surakarta is the pattern of Czuba, which is divided into 5 areas of community service, namely: engage contacts with individuals, groups and organizations thus can benefit the expertise of the university, contribute to the spiritual growth of the society, offering teaching services and research services, expertise exchange, providing access to facilities and / or programs, as well as special 
services related to the charter, vision, mission, goals and objectives of the university. Alternative patterns of community service can be used as the initial pattern for the development of community service activities. 


\section{REFERENCES}

Brunner, J. J., \& Gacel-avilà, J. (2012). Higher Education in Regional and City Development. Colombia: OECD.

Czuba, J. (2005). Relationship between university functions and community service at Divine Word University, 2(May), 57-67.

Morrow, W. (2009). Bounds of Democracy Epistemological Access in Higher Education. South Africa: HSRC Press.

Rahardjo, M. (2010). Sejarah Sosial Pengabdian kepada Masyarakat. Retrieved June 14, 2016, from https://www.uin-malang. ac.id/r/100501/sejarah-sosial-pengabdian-kepadamasyarakat.html

Smith, A. (2009). Perceptions of a university-school collaborative partnership. The University of Alabama.

UNESCO. (1998). World Declaration On Higher Education For The Twenty-First Century: Vision And Action. Paris. Retrieved from http://www.unesco.org/education/educprog/wche/ declaration_eng.htm

Wendler, W. V. (2010). Higher Education Policy Commentary. Illinois: Southern Illinois University Carbondale. 